Мрвоіин мищић

\title{
СТИЦАЈ ПРЕКРШАЈА
}

\section{Yeod}

Према законима о прекршајнма (Закон о прекршајима којн се повребују савезни пропюи - Сл. лист СФРЈ б́р. 4/77 и др., и Закан о прекршајима - Сл. гласник СРС бр. 44/89) шредвиьен је стицај прекршаја, и начин нзрицања јецинствене казне за прекршаје у стицају. Одредб́е оба закона у поглету материје стпцаја имају нелостапке, услед чета се у праксн појављуjу одреьени проб̆теми. У оба ова закона појам стицаја је у основи охребен на исти начин, као и начни отмеравања јединствене казне за прекршаје у стицају. Основин елементи стицаја оу: 1. да је учиньлаш јетном иля са више ралын учянно вเше прекршаја: 2. да о тим трекригајима ннје донето решење o прекршају; и 3 . да се поступак води пред истым органом. Ова законска дефнннпја стнцаја ствара потешкоће у разграничавану стищаја ад пюврата, јер се за стнцај прекршаја из. рнче јелннствене казна која лма свој максимум (60 дана затвора, ити двоструки износ највеће мере новчане каяне), док се за поврат кумулирају изречене казне. С.ве ово пропилази из чл. 38 натред цитираног савезног закона н 13 чл. 39 цитиранот репю́о̆тичкот закона.

\section{II. Паралелно одлучивање о стицају прехриаја}

У пракан се догаБа да исто лице у кратком временском периоду нзврип два нли више прекршаја за које је наллежан исти судија за прекршаје, да он истоврехено (парателно) за све прекршаје у стицају води одвојене постипке, да за сваки прекршај у стицају изрекне одвјену кажу, н да збор одвојено изречених казнн за сваки прекршај у стицају прелазн законом . дозвољенн макснмүм казне за прекршаје у стиају. Ова ситуашнја не би била од пиачаја, кала би у одредбама поменутих 
закона о прекршајима постојала одредб́а аналогна одредб́м чл. 401 ст. 1 тач. 1 Закона о кривичном постугку о неправом по-

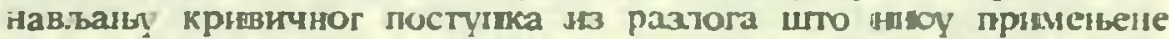
одретбе о нзрицању једннствене казне за крнвнчна дета у стнцају. Овим институтом кривнчног поступка обезбсьеiп је да се у свим стучајевима у којнма постојн стицај крнвичних дсла ооуьеном нзрекне јединствена казна. У нетостатку одредаба о неправсм понав.ъању ирекршајног постушка, постав.ьа се питање, да ли се може избери ситуација, да учниилащ за стнцај прекршаја не буде кажыьен збиром одвојено нзречелих казин за прекршаје у стицају, дакле зобиром казня који премашу је законокн макснмум казне за стицај прекршаја.

\section{III. Прочесне одредбе о спајању поступаха}

У чл. 121 Закона о ирекршајима СР Србије лротисано је да се слајање постулака вршн само у попледу санзвринлаца, а жије прехвиьено да се спајане постушка вршп и кала се ради о стицају прекршаја. Према тиме, капа су паралетно допета два иле више решења о прекршају гротив истог учнниоца иису повревене процесне одредб́е о спајању поступка у један поститак зобог прекршаја у стицају. Натротин, могло и́н се закљччнти да би биле повреБене охредбе чл. 121 Закина о лрекршајнма СР Срӧнје када би се нзвринто спајанс више паралелних поступака у којнма се огтучује о појединым прекршајнма којн се налазе у стицајр. Учинилац ирекршаја у стицају не и́я могао у жатбама против појелиних ретења о прекршају којн се натазе у стицају са остатим прекршајнма са устехом истицатя да је учитнлаи прекриаја у стнцају н да зо́нр норечених казни у свнм решеняма о појетндпи прекршајима у стнцају прелази максимум казне за грекршаје у стицају. Нелостатак одловарајућнх лроце:них идредо́н о спајању паралелних поститака о прекршајима у стицају спречава правилну примену матөрягашю правних охредаба о нзрниању јсиннствече казне за стнцај прекриаја. Овапво стање лроцеспих одрелбн, практично нскъучује примену матернјалио правюо инстнтута о стнцају прекршаја, олюосно институт стицаја претвара у инститт поврата за којн не важи огранпчеце о маконмүм! казне. Практично үчлюплац прөкрилаја у стнцају може бнти кажюен и са 80 ити випе дана затвора за стицај прекршаја ако се паралегно одлучује о сваком од њнх.

\section{IV. Критика материјалио правиих одредби о стицају}

Основни нетостатак материјалио гравних охредбн о стицају је што те одратбе сатрже противуречне елементе којн омогіћуjy строжије кажњанање за спицај прекршаја ол лрописаног максимума за стицај прекршаја. 
Увидно је речено да је елеменат стица: да се постүпак води лред истим органсм, а то hе рећи, да за све прекршаје у стицају мора битн налалежан нсти ортан. Напротив, ако то ншје случај, стниај се аутоматски претвара у пюврат. Поставља ce ıитање, зашто разлıчита наллежност за прекршаје у стицају може да има за последиц да учинилаи буде строжије кажњен за стицај прекршаја, дакле зӧнром казни којн прелаз макслмалну казну предвиьенг за прекршаје у стицају. По својој природи разцинита наллежност за сваки прекршај у стнцају није отежавајућа околност која би оправдавала строжнје кажььанаьье за прекршаје у стицају, услед чета је овај законоки е.теменат стщаја изван научнот појма о стицају, и у супротности је са казненом пюлитиком о кажњавању за стицај прекршаја.

Нсти је случај и каға се ради о елементу стицаја: да о прекршајнма у стицају није донето решење о прекршају, а то значи, да доношењем охвојенот решења о јалном прекршају у стицају остали прекршајн о којнма се волио паралелно поступак са првим прекршајсм се аутоматски налазе у поврат!, без об̆зра, што је први ирекршај о којем је донето решенье о прекршају касније гияњ ад прекршаја о којмма није донето решење о прекршају. Доношење решења о једном лрекршају у спщају, оилло неправноонажног, илн кала оно постане правюоснажно, није отежавајүћа околност која б̆и оиравтавала :трожије кажњњавые за стицај прекршаја од прописанот максимума казне за стнцај прекршаја, услед чега се овај законски елеменат стицаја прекршаја налази изван научног појма стицаја, а ујелно је н у супротности са политнком кажњавања за crйај прекршаја.

Оба напред наведена законока елемента стицаја практнчно нскључују прммену ннстытута стишаја, азносно стицај преıварају у поврат чнјн је правнш афекат у ситротности са правlikм ефектом стицаја.

Oдповарајићи законоки појам стицаја бйо о́и да се стюиајем сматра само стучај када је џчинилан са једном ит са внше радын учинио више прекршаја, јер овакав материјално правни појам стицаја oмоrtivjе кажњавање учпниоиа прекршаја у стицају у лраншиама прописанюг максимума кказне за стицај прекршаја.

\section{V. Зах.вучна ризматрања}

Решење изнетог пройтема нғје могуhe наһи у гүмачењу материјално правних и процесних одретой о прекршајима већ је потребона ктмена атредаба о спицају прекршаја тако да се из законске дефиниянје стицаја иакљүче елементн којн стицај претварају у поврат и на тај начни омогбћуј строжије кажњавање за стщцај прекршаја од законом предвнене мажсішилне казне за прекритаје у стицају. 
Надаље, котребна је и допуна лиоцесних одредаба увоьењем новог ванредног правног средства нетравном понавиьан,у прехршајњог постилка којлм бн се разрешила сва питана када је о прекриајнма у стнцају оллучивано у внше правноснално донетих решења о прекршају, јер би овај иниттут процеоно гарантовао учиниоцу прекршаја у стицају ца за стлцај прекршаја не може бити строжэјје кажнен ал макскмално пропнсане казне за прекршаје у стицају. 